\title{
The Influence of Learning Models and Cognitive Styles on Geography Learning Outcomes at SMAN 2 Percut Sei Tuan
}

\author{
Zuilen V Bay Sinaga ${ }^{1}$, Abdul Hamid K ${ }^{2}$, Sugiharto $^{3}$ \\ Education Technology Postgraduate Universitas Negeri Medan, Indonesia ${ }^{1,2,3}$ \\ zuilenvanboy16@gmail.com
}

\begin{abstract}
This study aims to: (1) Know the learning outcomes of students who are learning gography learning with problem based learning models and STAD learning models (2) to find out the geography learning outcomes of students who have independent cognitive styles, and dependent cognitive styles (3) know the interactions between learning models with cognitive styles in influencing student learning outcomes in geography. This research is a quasi-experimental research. Student learning outcomes taught by the problem based learning model are higher than students who are taught with the STAD learning model
\end{abstract}

Keywords: learning model, problem based learnig model learning, STAD learning model, cognitive style and learning outcomes

\section{Introduction}

One of the problems facing the world of education today is the weakness of the learning process in the classroom. In classroom learning students are not encouraged to develop thinking skills. The learning process in the classroom only encourages students to remember and memorize information [1]. Effective learning should prioritize the empowerment of students in processing information in the learning process. Teacher-oriented learning has to be changed by student-oriented learning, which is why a learning model is needed that encourages students to construct the existing knowledge within the students themselves. Geography lessons are considered very important because as a study of natural phenomena and life on earth as well as interactions between humans and the environment in relation to spatial and territorial relations or arrangement. Geography material in class XI IPS that discusses Indonesia as a World Maritime Axis is material that is It is very important for students to understand that our country is a unitary state that is connected by many islands. Students must also understand that our country has a lot of marine potential that must be exploited and enforced. The above material must be taught properly by using learning models that are able to foster student interest in learning, especially students who live close to sea areas such as Percut Sei Tuan [2] in her research concluded that there was a significant influence of PBL models on problem solving abilities. Gain score learning that uses PBL models is higher than conventional. The average value of the gain score of the experimental class was 22.9032 and the control was 11.0938. The results of the analysis of the Independent Sample T-Test, the difference shows the p-level value of 0,000 . The p-level value is smaller than 0.05 (p0.05). So, the conclusion "PBL model has a significant effect on the ability to solve high school geography problems." Research Karuniasih [3] The results of this study indicate that the ability to solve problems in students has increased 
from before being given an action that is $18 \%$ increased to $64.7 \%$ in Cycle I and increased again to $88.2 \%$ in Cycle II. Based on these results it can be concluded that by applying the PBL learning model the ability to solve the problem of Geography lessons of students has increased.

Research conducted by Istianah [4] showed that the application of the Problem Based Learning model could improve students' critical thinking skills. In the first cycle, the average value of students' critical thinking skills reached 55.97, while in the implementation of the second cycle actions 74.81. Based on these results it is known that an increase in critical thinking skills is $33.66 \%$. The conclusion of this research is that the application of the Problem Based Learning model can improve the critical thinking skills of students of class X IPS-I of SMA Laboratory of State University of Malang on atmospheric material. The objectives of this study are (1) To find out the differences in the learning outcomes of students who are taught by the learning model of problem-based learning and the learning outcomes of students who are taught with the STAD type learning model. (2) Knowing the differences in geography learning outcomes of students who have independent field cognitive styles and geography learning outcomes of students who have field dependent cognitive styles. (3) Knowing the significant interaction between learning models and cognitive styles in influencing student learning outcomes in geography

\section{Research Method}

This research is a quasy experiment research because in this study the class that received treatment (experiment) is a class that has been previously formed without changing the situation and conditions of the class that has been formed which aims to approach estimates for the state that can be achieved through actual experiments in circumstances that make it impossible to control and / or manipulate all relevant variables. One sample class was given treatment with the implementation of learning using the problem-based learning (PBL) learning model and another class was given treatment by implementing learning using the Student Team Achievement Divisions (STAD) learning model.

\section{Result and Discussion}

Table 1. Summary of Data from Descriptive Analysis Calculation Results

\begin{tabular}{lllll}
\hline & STATISTIK & PBL & STAD & JUMLAH \\
\hline Field & $\mathrm{N}$ & 20 & 12 & 32 \\
Independent & $\sum \mathrm{X}$ & 684 & 334 & 1018 \\
& $\sum \mathrm{X}$ & 23552 & 9386 & 32938 \\
\multirow{5}{*}{ Field Dependent } & $\mathrm{M}$ & 34,2 & 27,83 & 31,81 \\
& $\mathrm{~N}$ & 10 & 19 & 29 \\
& $\mathrm{X}$ & 318 & 564 & 882 \\
& $\sum \mathrm{X}^{2}$ & 10168 & 16898 & 27066 \\
JUMLAH & $\mathrm{M}$ & 31,8 & 29,68 & 30,41 \\
& $\mathrm{~N}$ & 30 & 31 & 61 \\
& $\mathrm{X}$ & 1002 & 898 & 1900 \\
& $\sum \mathrm{X}^{2}$ & 33720 & 26284 & 60004 \\
& $\mathrm{M}$ & 33,4 & 28,96 & 62,36 \\
\hline
\end{tabular}


Table 2. 2-way ANOVA analysis results $2 \times 2$ factorial

\begin{tabular}{llllll}
\hline Sumber varian & JK & db & RJK & Fhitung & Ftabel \\
\hline Antar baris & 299,51 & 1 & 29,76 & 4,66 & \\
Antar kolom & 29,76 & 1 & 299,51 & 36,93 & 4,01 \\
Antar baris dan kolom (interaksi) & 31,73 & 1 & 31,73 & 5,91 & \\
Dalam kelompok kekeliruan & 462,67 & 57 & 8,11 & - & \\
\hline Total & & 61 & - & - & \\
\hline
\end{tabular}

a. The first hypothesis

The first hypothesis testing is the learning outcomes of students' geographies that are taught using the PBL learning model are different from the groups of students who are taught by the STAD learning model. From the results of data analysis, it was found that the average geography learning outcomes of groups of students who were taught with PBL learning models was 33.4 and the average results of learning geography of students who were taught with STAD learning models of 28.96. Based on Anova calculation, Fcount was 3.66 while Ftable was 4.01 so Ho was rejected. Thus it can be concluded that the geography learning outcomes of groups of students who were taught with the PBL learning model were higher than the groups of students who were taught with the STAD Class learning model whose truth was tested.

\section{b. The second hypothesis}

The second hypothesis testing is the learning outcomes of groups of students who have a cognitive style of FI and FD From the results of data analysis found the average geography learning outcomes of students who have a Field Independent cognitive style of 31.81 and the average geography learning outcomes that have a field dependent cognitive style of 30.41 . Based on the Anova calculation, it was obtained that the F count was 36.93 while the F table4.01 so that Ho was rejected. Thus it can be concluded that the geography learning outcomes of groups of students who have independent cognitive field style is higher than the group of students who have field dependent cognitive styles whose truth is tested.

\section{c. Third hypothesis}

The third hypothesis testing is the interaction between learning models and cognitive styles on geography learning outcomes. Based on data analysis found the average value of student geography learning outcomes taught with PBL models that have independent field cognitive styles of 34.2 and the average geographic learning outcomes learned with PBL learning models that have field dependent cognitive styles of 31.8 , then the average geography learning outcomes of the students studied with the STAD learning model that has an independent field cognitive style of 27.83 and the average geography learning outcomes of students taught with the STAD learning model that has a field dependent cognitive style of 29.68 Based on the Anava calculation, Fcount5.91, while Ftable 4.01 for dk (1.57) with a 5\% significance level, it turns out that the calculated $\mathrm{F}$ value is $5.91>\mathrm{F}$ table 3.98 so that Ho is rejected. Thus it can be concluded that there is an interaction between learning models and cognitive styles on geography learning outcomes.

\section{Conclusion}

1. There are differences in geography learning outcomes taught using PBL learning models compared to using STAD learning models, student geography learning outcomes taught 
with PBL learning models are higher than student Geography learning outcomes using STAD learning models.

2. There are differences in learning outcomes of independent and field dependent cognitive style geography, independent field geography learning outcomes are higher than field dependent geography learning outcomes

3. There is an interaction between learning models and students' cognitive styles on geography learning outcomes, students who have independent field cognitive styles and are taught with PBL models are higher than students who have field dependent cognitive styles and are taught with STAD model learning models.

\section{References}

[1] Sanjana, W. Standard Process Oriented Learning Strategies. Jakarta. Kencana, Prenada Media Group (2006).

[2] Larasati, Diyas Age. The Effect of Problem Based Learning Models on High School Geography Problem Solving Capabilities. Thesis, Geography Education Study Program, PostSarjana, State University of Malang (2014).

[3] Karuniasih, et al. Application of Problem Based Learning Model to Improve the Ability to Solve Geography Lessons in Class XI IPS 2 Sma N 8 Malang Students (online). http://jurnalonline.um.ac.id/data/artikel/artikelCFF48F427FEBC003B $\quad$ C062C0F88 E1F5EF.pdf (accessed on Monday 27 May 2019).

[4] Istianah 2015, Application of Problem Based Learning (PBL) Learning Model to Improve Critical Thinking Ability in Learning Geography Class XIPS-I of SMA Laboratory of State University of Malang (online) http: // Karya- scientific.um.ac.id/index. php / Geography / article / view / 40070 (accessed Monday May 27 2019). 